\title{
Biochemical and Chemical Studies on Strains Designated Prevotella intermedia and Proposal of a New Pigmented Species, Prevotella nigrescens sp. nov.
}

\author{
HAROUN N. SHAH ${ }^{1,2 *}$ AND SAHEER E. GHARBIA ${ }^{1}$ \\ Department of Oral Biology, ${ }^{1}$ Faculty of Dentistry, and Department of Microbiology and Immunology, ${ }^{2}$ \\ Faculty of Medicine, Dalhousie University, Halifax, Nova Scotia, Canada B3H 3J5
}

\begin{abstract}
A total of 31 strains of Prevotella intermedia were subjected to DNA-DNA hybridization and were characterized by performing physiological tests and by performing a multilocus enzyme analysis, using malate dehydrogenase and glutamate dehydrogenase. All of the strains assigned to $P$. intermedia fermented glucose and sucrose, hydrolyzed starch but not esculin, and produced indole, acetic, isobutyric, isovaleric, and succinic acids as metabolic end products. The results of DNA reassociation experiments performed with the reference probe permitted separation of the strains into two well-defined homology groups. In addition, strains with DNAs that hybridized with DNA from strain ATCC $25611^{\mathrm{T}}$ ( $T=$ type strain) had high levels of peptidase activity and cleaved lipid substrates (4-methylumbelliferyl laurate and 4-methylumbellifelyl elaidate). Multilocus enzyme electrophoresis revealed two electromorphic profiles, one characteristic of strain ATCC $25611^{T}$ and the other characteristic of strain ATCC $33563^{\mathrm{T}}$. We propose that a new species, Prevotella nigrescens, should be created for the genetically distinct group of strains that hybridized with strain ATCC $33563^{\mathrm{T}}$. Strain ATCC 33563 is designated the type strain of $P$. nigrescens.
\end{abstract}

The "black-pigmented bacteroides" have undergone major taxonomic revisions at both the generic and species levels within the last decade (for a review, see reference 14). Strains that ferment carbohydrates have been assigned to the genus Prevotella (19), while most of the strains that are asaccharolytic have been placed in the genus Porphyromonas (18). The taxonomic position of the weakly saccharolytic taxa Bacteroides levii and Bacteroides macacae remains uncertain and needs further investigation. The most saccharolytic strains (formerly Bacteroides melaninogenicus subsp. melaninogenicus [6]) have been placed in three species, Prevotella melaninogenica, Prevotella loescheii, and Prevotella denticola (19). On the basis of biochemical and chemical characteristics, the nonfermentative strains have been placed in the species Porphyromonas asaccharolytica, Porphyromonas gingivalis, and Porphyromonas endodontalis $(2,17,28)$. Bacteroides salivosus, a nonfermentative species isolated from cats, has been reassigned recently to the genus Porphyromonas, and a new species, Porphyromonas circumdentaria, has been proposed (12).

Strains which ferment only a limited range of carbohydrates and which were recognized previously as $B$. melaninogenicus subsp. intermedius strains have been elevated to species rank as Bacteroides intermedius (7). However, the fact that there is heterogeneity within this species has been recognized for some time. Lambe (11) and Lambe and Terris (10) reported serological differences among isolates and described two serotypes, serotypes $C$ and $C_{1}$. We demonstrated that there were differences in sodium dodecyl sulfate polypeptide patterns among strains and reported that the electrophoretic profile of serotype $C_{1}$ strains was markedly different from the electrophoretic profiles of other strains of this species (25). Subsequent DNA-DNA homology studies by Johnson and Holdeman (7) confirmed the differences between serotypes, and a new species, Bacteroides corporis, was created for serotype $C_{1}$ strains (7). Both $B$. intermedius

\footnotetext{
* Corresponding author.
}

and $B$. corporis have now been incorporated in the recently proposed genus Prevotella. Heterogeneity within Prevotella intermedia has been demonstrated by a variety of methods, but no attempts have been made to clarify the taxonomic status of strains which belong to this species $(3,4,7,13,23$, $25,27)$. In this study we used a variety of physiological tests, multilocus enzyme electrophoretic analysis, and DNA-DNA hybridization to investigate the intraspecies diversity in Prevotella intermedia.

\section{MATERIALS AND METHODS}

Strains. The sources and sites of isolation of the strains used in this study have been described previously $(3,4,7$, $23,25,26,28)$. Strains with designations that begin with DAL have been characterized at Dalhousie University and were isolated from human dental plaque.

Cultivation and identification. All strains were maintained by twice-weekly subculturing on $5.0 \%$ (vol/vol) blood agar plates in an atmosphere containing $10 \%$ (vol/vol) $\mathrm{CO}_{2}$ and $5 \%$ (vol/vol) $\mathrm{H}_{2}$ in $\mathrm{N}_{2}$ at $37^{\circ} \mathrm{C}$. After 2 days of growth, bacterial suspensions with densities corresponding to a McFarland no. 4 density standard were used to inoculate API 20A trays as described previously (9). The identities of strains were also confirmed by analyzing their metabolic end products as described previously (23).

Peptidase and lipase activities. Aminopeptidase activity was tested by using 4-methylcoumarin-labeled peptides. Hydrolytic activity was recorded after $3 \mathrm{~h}$ of incubation at $37^{\circ} \mathrm{C}$ by using $100 \mathrm{ml}$ of a cell suspension of each strain along with $100 \mathrm{ml}$ of a $1.5-\mathrm{mg} / \mathrm{ml}$ solution of substrate. Peptidase activity was indicated by an increase in fluorescence under UV radiation ( $300 \mathrm{~nm})$ and by a color change at $412 \mathrm{~nm}$ for the 4-methylcoumarin and $p$-nitroanilide substrates, respectively. The following methylcoumarin-labeled peptides were tested; $N$-succinyl-L-leucyl-leucyl-valyl-tyrosyl-, BOCleucyl-seryl-threolyl-arginyl-, succinyl-alanyl-alanyl-phenylalanyl-, $N$-benzoyl-L-phenylalanyl-valyl-arginyl-, $N$-CBZ-glycyl-glycyl-arginyl-, and glycyl-prolyl-4-methylcoumarin. The 
following $p$-nitroanilide substrates were tested; $N$-succinylL-arginyl-arginine-, $S$-benzoyl-L-cysteine-, and $N$-benzoylphenylalanine- $p$-nitroanilide. Lipolytic activity was initially observed on egg yolk agar (24) after $24 \mathrm{~h}$ of incubation. Cell suspensions were also tested for lipolytic activity as described above for laurate-, nanoate-, and elaidate-4-methylumbelliferyl fluorescence-labeled fatty acids.

Preparation of cell extracts and enzyme electrophoresis. Cells were harvested from 2-day-old blood agar cultures and were suspended in $0.5 \mathrm{ml}$ of $0.1 \mathrm{M}$ Tris $\mathrm{HCl}$ buffer $(\mathrm{pH} 7.5)$. Each cell suspension was shaken with Ballotini beads (grade 12) for $10 \mathrm{~min}$ in a Mickle tissue disintegrator at $4^{\circ} \mathrm{C}$. Each mixture was centrifuged at $37,000 \times g$ for $10 \mathrm{~min}$, and the supernatants were electrophoresed by using a Fisher Biotech model FB105 constant-voltage power supply and a Peltier model FB1001 thermoelectric module. The temperature was maintained precisely during electrophoresis by the Peltier elements at $8.0 \pm 0.1^{\circ} \mathrm{C}$. Electrophoresis was carried out for $90 \mathrm{~min}$ at $14.8 \mathrm{~V} / \mathrm{cm}$ of gel in $0.04 \mathrm{M}$ barbitone-acetic acid buffer ( $\mathrm{pH} 8.6$ ). Glutamate dehydrogenase was visualized by using a solution containing glutamate $(20 \mathrm{mg} / \mathrm{ml})$, NAD $(5 \mathrm{mg} / \mathrm{ml})$, phenazine methosulfate $(0.04 \mathrm{mg} / \mathrm{ml})$, and thiazolyl blue tetrazolium $(0.02 \mathrm{mg} / \mathrm{ml})$ in $0.1 \mathrm{M}$ Tris $\mathrm{HCl}$ buffer ( $\mathrm{pH}$ 9.0). Malate dehydrogenase was visualized by replacing the glutamate with a solution of L-malic acid (10 $\mathrm{mg} / \mathrm{ml}$ ) neutralized with $\mathrm{NaHCO}_{3}$.

DNA isolation, purification, and base composition determination. All strains were cultured in BM medium containing $1 \%$ (vol/vol) glycine to assist in the lysis of cells (23). DNAs were prepared from all strains as described previously (23). DNA base composition was estimated from the melting temperature of the DNA in saline citrate $(0.15 \mathrm{M} \mathrm{NaCl}$ plus $0.015 \mathrm{M}$ trisodium citrate, $\mathrm{pH} 7.0$ ) by using a Hewlett Packard model HP8452A diode array spectrophotometer equipped with a model HP89090A Peltier temperature controller and type HP89532A software (Hewlett-Packard Co. Palo Alto, Calif.).

Preparation of labeled nucleic acid. Both reference DNA preparations were dialyzed against deionized water for $48 \mathrm{~h}$ before labeling. For hybridization experiments, $3 \mu \mathrm{g}$ of each reference DNA was labeled in vitro with $\left[1^{\prime}, 2^{\prime}, 5^{-} \mathrm{H}\right] \mathrm{dCTP}$ by nick translation (8), using a commercial nick translation kit (Amersham Corp., Arlington Heights, Ill.). The reaction was terminated after $40 \mathrm{~min}$, and the DNA was separated from unincorporated nucleotides by gel exclusion chromatography through Sephadex G-50 and was dialyzed against $0.42 \mathrm{M} \mathrm{NaCl}$. The DNA was sheared by sonication for $3 \mathrm{~min}$ with a $3-\mathrm{mm}$ probe at a power setting of 7 (3 to $4 \mathrm{~A}$ for three 10-s bursts).

DNA-DNA hybridization. DNA homology experiments were performed as described previously (21), with minor modifications. The unlabeled DNAs to be used for all hybridization experiments were dialyzed against $0.42 \mathrm{M}$ $\mathrm{NaCl}$ and sheared as described above to give a fragment size of approximately $500 \mathrm{bp}$. A reaction mixture containing 0.02 $\mu \mathrm{g}$ of the labeled reference DNA and $20 \mu \mathrm{g}$ of unlabeled DNA was mixed in $200 \mu \mathrm{l}$ of $0.42 \mathrm{M} \mathrm{NaCl}$, and $200 \mu \mathrm{l}$ of light paraffin oil was layered on top. The mixture was denatured for $10 \mathrm{~min}$ at $100^{\circ} \mathrm{C}$, and hybridization was allowed to proceed for $90 \mathrm{~h}$ at $70^{\circ} \mathrm{C}$. The tubes were then placed in an ice bath for $20 \mathrm{~min}$ to stop the reactions. S1 nuclease (100 $\mathrm{U} / \mathrm{ml}$; Sigma Chemical Co., St. Louis, Mo.) in a buffer containing $0.1 \mathrm{mM} \mathrm{ZnSO}_{4}, 0.15 \mathrm{M} \mathrm{NaCl}, 30 \mathrm{mM}$ sodium acetate ( $\mathrm{pH} \mathrm{4.5)}$, and $20 \mathrm{mg}$ of sheared and denatured calf thymus DNA (type V; Sigma) per ml was added to all of the tubes. The mixture was incubated for $20 \mathrm{~min}$ at $50^{\circ} \mathrm{C}$, precipitated with $10 \%$ trichloroacetic acid, and filtered through membrane filters (Schleicher \& Schuell, Dassel, Germany). Cocktail T scintilation fluid (BDH Inc., Dartmouth, Nova Scotia, Canada) was added to the filters, which were counted by using a model LS3133T liquid scintillation counter (Beckman Instruments, Inc.). The level of hybridization in each reaction was determined as a percentage of the value for the homologous reaction. The level of recovery of labeled DNA in the homologous reaction was $80 \%$. A correction was made for self-reassociation of labeled DNA by using calf thymus DNA as a control.

\section{RESULTS AND DISCUSSION}

The strains used in this study had biochemical properties that were consistent with those reported previously for Prevotella intermedia (3, 5, 7, 23). All of these strains characteristically produced black to dark brown colonies on blood agar plates within 2 to 5 days of subculturing and exhibited red fluorescence under long-wave UV radiation $(365 \mathrm{~nm})$, particularly toward the centers of the colonies. Most strains exhibited weak hemolysis, but a few, such as strains T588 and M107, were alpha-hemolytic. The cells typically fermented glucose and sucrose, hydrolyzed starch but not esculin, and produced indole, acetic, isobutyric, isovaleric, and succinic acids as end products of metabolism in BM medium (23).

The DNA base compositions of all of the strains ranged between 40 and $44 \mathrm{~mol} \% \mathrm{G}+\mathrm{C}$, in accord with previously published data $(7,23,27)$. The two strains selected for use as DNA probes in this study have been shown previously to represent at least two centers of variation among strains labeled Prevotella intermedia $(7,27)$. In the previous studies, reciprocal hybridizations between members of the two groups of isolates revealed approximately $40 \%$ DNA-DNA homology, perhaps because of the lower stringency of the reassociation experiments. In this study, our hybridization experiments, which were carried out under higher-stringency conditions $\left(70^{\circ} \mathrm{C}\right)$ (see Materials and Methods), revealed two groups of strains that were clearly discernible. Eleven strains hybridized with strain ATCC $25611^{\mathrm{T}}(\mathrm{T}=$ type strain), and this group of strains was designated group 1 ; the levels of hybridization with strain ATCC $25611^{\mathrm{T}}$ were high ( 72 to $92 \%$ ), and the levels of hybridization with the strain ATCC $33563^{\mathrm{T}}$ DNA probe were less than $20 \%$ (Table $1)$. The remaining 18 strains exhibited high levels of DNA homology with strain ATCC $33563^{\mathrm{T}}$ (81 to $98 \%$ ) and very low levels of homology with strain ATCC $25611^{\mathrm{T}}$ (Table 1); this second group of strains was designated group 2 .

Of the substrates used to test for peptidase activity, hydrolysis of the dipeptide glycyl-proline clearly differentiated the two DNA homology groups (Table 2). Similarly, the two groups were resolved by using the fluorescence-labeled fatty acid substrates 4-methylumbelliferyl-laurate and 4-methylumbelliferyl-elaidate. The group 1 strains exhibited pronounced esterase activity against both substrates, whereas the group 2 strains were negative for this characteristic (Table 2). The higher lipolytic activities of the group 1 strains were also demonstrated on egg yolk agar (24). Thus, whereas the group 1 strains possessed lipase activity after $24 \mathrm{~h}$, the group 2 strains exhibited activity only after $48 \mathrm{~h}$.

The use of multilocus enzyme electrophoresis has been valuable for clarifying the taxonomy of black-pigmented species which previously were placed in the genus Bacteroides $(1,17,22)$. In this study, the use of both malate dehydrogenase and glutamate dehydrogenase resulted in 
TABLE 1. DNA-DNA hybridization of Prevotella intermedia

\begin{tabular}{|c|c|c|c|}
\hline \multirow{2}{*}{ Strain } & \multirow{2}{*}{$\begin{array}{c}\mathrm{G}+\mathrm{C} \text { content } \\
(\mathrm{mol} \%)\end{array}$} & \multicolumn{2}{|c|}{$\begin{array}{l}\% \text { Hybridization with } \\
{\left[{ }^{3} \mathrm{H}\right] \mathrm{DNA} \text { from: }}\end{array}$} \\
\hline & & $\begin{array}{l}\text { Strain ATCC } \\
2_{25611^{\mathrm{T}}}\end{array}$ & $\underset{33563^{\mathbf{T}}}{\text { Strain ATCC }}$ \\
\hline ATCC $25611^{\mathrm{T}}$ & 44.2 & 100 & 17 \\
\hline N275-70A & $\mathrm{NT}^{a}$ & 92 & 16 \\
\hline $3 b$ & 43.8 & 88 & 6 \\
\hline S581 & NT & 86 & 19 \\
\hline OMZ 248 & 42.7 & 82 & 15 \\
\hline OMZ 268 & 43.1 & 82 & 17 \\
\hline B9 & 43.4 & 78 & 11 \\
\hline DAL 11 & 44.1 & 75 & 14 \\
\hline DAL 15 & 43.3 & 75 & 12 \\
\hline DAL 17 & 41.8 & 74 & 15 \\
\hline DAL 36 & 42.4 & 74 & 16 \\
\hline DAL 41 & 43.0 & 72 & 11 \\
\hline ATCC $33563^{\mathrm{T}}$ & 42.5 & 13 & 100 \\
\hline LM 107 & 42.0 & 11 & 98 \\
\hline T588 & 42.6 & 15 & 94 \\
\hline OMZ 251 & NT & 19 & 93 \\
\hline B18 & 43.2 & 12 & 88 \\
\hline B22 & NT & 9 & 87 \\
\hline B23 & 41.7 & 7 & 87 \\
\hline G11A-d2 & NT & 10 & 86 \\
\hline D13a-f1 & 43.7 & 16 & 88 \\
\hline NCTC 9338 & 42.6 & 13 & 88 \\
\hline S377 & NT & 11 & 87 \\
\hline M107 & 42.8 & 12 & 86 \\
\hline OMZ 265 & NT & 7 & 86 \\
\hline T584 & 42.9 & 5 & 84 \\
\hline DAL 100 & 44.2 & 17 & 84 \\
\hline DAL 106 & 44.0 & 19 & 83 \\
\hline DAL 112 & 42.6 & 13 & 83 \\
\hline DAL 116 & 43.2 & 11 & 83 \\
\hline DAL 121 & 42.9 & 12 & 81 \\
\hline
\end{tabular}

${ }^{a} \mathrm{NT}$, not tested.

unambiguous separation of the two DNA homology groups. The group 1 strains had enzyme electrophoretic mobilities that were faster than those of the group 2 strains (Fig. 1) and therefore provided a rapid way to identify unknown isolates.

The identification of two DNA homology groups among human Prevotella intermedia isolates has been reported previously $(7,27)$. These isolates have been subdivided into three serotypes, serotypes I, II, and III, by using monoclonal antibodies (4). In this study we found no test, including

TABLE 2. Peptidase and lipase activities of test strains

\begin{tabular}{lcc}
\hline \multicolumn{1}{c}{ Substrate } & \multicolumn{2}{c}{ Activity in: } \\
\cline { 2 - 3 } & $\begin{array}{c}\text { Strain ATCC } \\
25611^{\mathrm{T}} \\
\text { homology group }\end{array}$ & $\begin{array}{c}\text { Strain ATCC } \\
33563^{\mathrm{T}} \\
\text { homology group }\end{array}$ \\
\hline$N$-Succinyl-L-Leu-Leu-Val-tyrosyl & + & + \\
BOC-Leu-Ser-Thr-arginyl & $-+^{a}$ & - \\
Succinyl-Ala-Ala-phenylalanyl & + & + \\
$N$-Benzoyl-phenyl-Ala-Val-arginyl & - & -+ \\
$N$-CBZ-Gly-Gly-arginyl & -+ & - \\
Gly-proline & + & - \\
Laurate & + & - \\
Nanoate & + & +- \\
Elaidate & + & - \\
\hline
\end{tabular}

$a-+$, most strains are negative, and a few strains are weakly positive. $b+-$, most strains are positive, and a few strains are weakly negative.

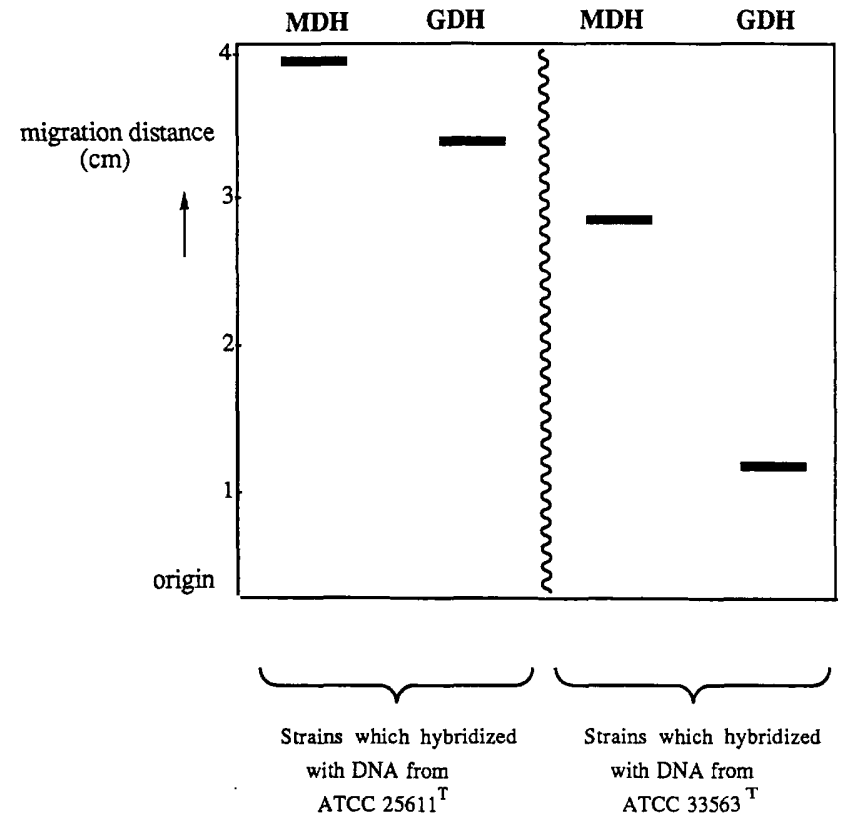

FIG. 1. Electrophoretic migration distances of malate dehydrogenases (MDH) and glutamate dehydrogenases (GDH) of Prevotella intermedia and related strains.

DNA-DNA hybridization (81 to $100 \%$ ), that separated serotypes II and III. We believe that strains which presently belong to II and III serotypes should be retained in a single species that is separate from the DNA homology group 1 strains (20).

In previous studies we reported that strains belonging to the two DNA homology groups possessed similar chemotaxonomic properties. Thus, all of the strains contained menaquinones as their sole isoprenoid quinones, and menaquinones containing 11 isoprene units were major components $(1,16,17)$. The long-chain cellular fatty acids of these organisms were mainly 12-methyltetradecanoic acid (anteiso- $\mathrm{C}_{15: 0}$ ); lower levels of 12-methyltridecanoic acid (iso$\mathrm{C}_{14: 0}$ ) and 13-methyltetradecanoic acid (iso- $\mathrm{C}_{15: 0}$ ) were also present $(1,16,17)$. Similarly, representative strains belonging to the two groups contained both protoheme and protoporphyrin as major pigments $(1,15,17)$. However, the tests used in this study clearly delineated two groups of strains; some of these strains were isolated from patients with periodontitis, whereas others were isolated from healthy individuals. Clearer circumscription of the species may facilitate a better understanding of the role of these organisms in disease.

In summary, our results demonstrate unequivocally that strains previously placed in the species Prevotella intermedia are members of two genetic groups. One group contains the type strain of Prevotella intermedia (strain ATCC $25611^{\mathrm{T}}$ ) and should therefore be retained as the species Prevotella intermedia. However, the remaining strains differ markedly from strain ATCC $25611^{\mathrm{T}}$ in DNA-DNA hybridization characteristics, peptidase and lipase activities, and multilocus enzyme electrophoretic profiles. We propose that a new species, Prevotella nigrescens, should be created for the genetically distinct group of strains that hybridize with strain ATCC 33563 and that strain ATCC 33563 should be designated the type strain. A full description of this species, 
TABLE 3. Biochemical reactions that are useful for distinguishing Prevotella nigrescens from Porphyromonas species and black-pigmented Prevotella species

\begin{tabular}{|c|c|c|c|c|c|c|}
\hline Species & $\begin{array}{c}\text { Indole } \\
\text { production }\end{array}$ & $\begin{array}{c}\text { Lipase } \\
\text { production }\end{array}$ & $\begin{array}{l}\text { Acid produced } \\
\text { from glucose }\end{array}$ & $\begin{array}{l}\text { Acid produced } \\
\text { from lactose }\end{array}$ & $\begin{array}{l}\text { Acid produced } \\
\text { from } \\
\text { cellobiose }\end{array}$ & $\begin{array}{l}\text { Metabolic end } \\
\text { products }^{a}\end{array}$ \\
\hline Porphyromonas asaccharolytica & + & - & - & - & - & $A, B, S, i b, p, i v$ \\
\hline Porphyromonas endodontalis & + & - & - & - & - & $\mathrm{B}, \mathrm{IV}, \mathrm{a}, \mathrm{s}$ \\
\hline Porphyromonas gingivalis & + & - & - & - & - & B,IV,PA,a,p,ib,s \\
\hline Prevotella intermedia & + & + & + & - & - & A,S,iv (ib,p) \\
\hline Prevotella nigrescens & + & - & + & - & - & $A, S, i v(i b, p)$ \\
\hline Prevotella corporis & - & - & + & - & - & $A, s, i b$, iv (b) \\
\hline Prevotella melaninogenica & - & - & + & + & - & A,S (ib,iv,l) \\
\hline Prevotella denticola & - & - & + & + & - & A,S (ib,iv,l) \\
\hline Prevotella loescheii & - & - & + & + & + & a,S $(1)$ \\
\hline
\end{tabular}

a Abbreviations: A and a, acetic acid; $\mathrm{B}$ and b, butyric acid; l, lactic acid; p, propionic acid; ib, isobutyric acid; IV and iv, isovaleric acid; S and s, succinic acid; PA, phenylacetic acid. Upper case letters indicate primary end products, and lower case letters indicate secondary end products.

which incorporates data from several studies $(1,3-5,7,11$, $13,15-18,22,23,25-27)$, is given below. Table 3 shows characteristics which distinguish Prevotella nigrescens from other related black-pigmented species.

Description of Prevotella nigrescens sp. nov. Prevotella nigrescens (ni.gres'cens. L. part. adj. nigrescens, becoming black, referring to the characteristic black colonies formed on blood agar plates) is a gram-negative, nonsporing, obligately anaerobic, rod-shaped organism. Cells grown in broth cultures are 0.3 to $0.7 \mu \mathrm{m}$ wide by 1 to $2 \mu \mathrm{m}$ long; some cells may be ca. 6 to $10 \mu \mathrm{m}$ long. Surface colonies after 3 days on horse blood agar are 0.5 to $2 \mathrm{~mm}$ in diameter, circular, entire, low convex, smooth, and brown to black. Pigmentation commonly occurs around the periphery of the colonies, while the center is cream to dark brown. Most colonies exhibit bright red fluorescence under UV radiation $(365 \mathrm{~nm})$, particularly toward the less pigmented center of each colony. Most strains are weakly hemolytic, but a few are alpha-hemolytic.

The major fermentation products from a glucose-containing broth are acetic, isobutyric, isovaleric, and succinic acids. Dextrin, glucose, maltose, and sucrose are fermented by most strains, while the fermentation of fructose, glycogen, and inulin is variable. Indole is produced. Starch, but not esculin, is hydrolyzed. Gelatin is digested. The following commonly used test carbohydrates are not fermented: amygdalin, arabinose, cellobiose, inositol, lactose (two strains have been reported to ferment lactose), mannitol, melezitose, melibiose, rhamnose, ribose, salicin, trehalose, and xylose. Of the constitutive enzymes tested by using the API ZYM system, acid and alkaline phosphatases, phosphoamidase, and $\beta$-glucosidase consistently give strong positive reactions. Weak reactions occur for butyrate esterase and caprylate esterase lipase. $\alpha$-Fucosidase activity varies among strains.

Diaminopimelic acid is the only dibasic amino acid present in the peptidoglycan. The major pigments produced are protoheme and protoporphyrin. Malate and glutamate dehydrogenases are present. Glucose-6-phosphate and 6-phosphogluconate dehydrogenases are absent. The major cellular fatty acid is 12 -methyltetradecanoic acid (anteiso- $\mathrm{C}_{15: 0}$ ). The principal respiratory quinones are unsaturated menaquinones. The $\mathrm{G}+\mathrm{C}$ content of the DNA is 40 to $44 \mathrm{~mol} \%$.

The type strain is strain ATCC 33563 (= NCTC $9336=$ VPI $8944=$ Lambe 729-74) (serogroup C).

\section{ACKNOWLEDGMENT}

We acknowledge the support of Canadian Medical Research Council Development grant DG-411.

\section{REFERENCES}

1. Collins, M. D., and H. N. Shah. 1987. Recent advances in the chemotaxomomy of the genus Bacteroides, p. 249-258. In S. P. Borriello, J. M. Hardie, B. S. Draser, B. I. Duerden, M. J. Hudson, and R. J. Lysons (ed.), Recent advances in anaerobic bacteriology. Martinus Nijhoff Publishers, Boston.

2. Coykendall, A. L., F. S. Kaezmarek, and J. Slots. 1980. Genetic heterogeneity in Bacteroides asaccharolyticus (Holdeman and Moore, 1970; Finegold and Barnes, 1977; Approved Lists, 1980) and proposal of Bacteroides gingivalis sp. nov. and Bacteroides macacae (Slots and Genco) comb. nov. Int. J. Syst. Bacteriol. 30:559-564.

3. Dahlen, G., M. Wikstrom, S. Renvert, R. Gmur, and B. Guggenheim. 1990. Biochemical and serological characterization of Bacteroides intermedius strains isolated from the deep periodontal pocket. J. Clin. Microbiol. 28:2269-2274.

4. Gmur, R., and B. Guggenheim. 1983. Antigenic heterogeneity of Bacteroides intermedius as recognized by monoclonal antibodies. Infect. Immum. 42:459-470.

5. Holdeman, L. V., R. W. Kelly, and W. E. C. Moore. 1984. Genus Bacteroides, p. 604-631. In N. R. Krieg and J. G. Holt (ed.), Bergey's manual of systematic bacteriology, vol. 1. The Williams \& Wilkins Co., Baltimore.

6. Holdeman, L. V., and W. E. C. Moore. 1974. Gram-negative anaerobic bacteria, p. 384-404. In R. E. Buchanan and N. E. Gibbons (ed.), Bergey's manual of determinative bacteriology, 8 th ed. The Williams \& Wilkins Co., Baltimore.

7. Johnson, J. L., and L. V. Holdeman. 1983. Bacteroides intermedius comb. nov. and descriptions of Bacteroides corporis sp. nov. and Bacteroides levii sp. nov. Int. J. Syst. Bacteriol. 33:15-25.

8. Kelly, R. B., N. R. Cozzarelli, M. P. Deutscher, I. R. Lehman, and A. Kornberg. 1970. Enzymatic synthesis of deoxyribonucleic acid. XXXII. Replication of complex deoxyribonucleic acid by polymerase at a single strand break. J. Biol. Chem. 245:39-45.

9. Knivett, V. A., H. N. Shah, A. S. McKee, and J. M. Hardie. 1983. Numerical taxonomy of some non-saccharolytic and saccharolytic Bacteroides species. J. Appl. Bacteriol. 55:71-80.

10. Lambe, D. W., and R. C. Terris. 1976. Description of a polyvalent conjugate and a new serogroup of Bacteroides melaninogenicus by fluorescent antibody staining. J. Clin. Microbiol. 3:506-512.

11. Lambe, D. W., Jr. 1974. Determination of Bacteroides melaninogenicus serogroups by fluorescent antibody staining. Appl. Microbiol. 28:561-567.

12. Love, D. N., G. D. Bailey, S. Collings, and D. A. Briscoe. 1992. 
Description of Porphyromonas circumdentaria sp. nov. and reassignment of Bacteroides salivosus (Love, Johnson, Jones, and Calverley 1987) as Porphyromonas (Shah and Collins 1988) salivosa comb. nov. Int. J. Syst. Bacteriol. 42:434-438.

13. Reed, M., J. Slots, C. Mouton, and R. T. Genco. 1980. Antigenic studies of oral and nonoral black-pigmented Bacteroides strains. Infect. Immun. 29:564-574.

14. Shah, H. N. 1991. The genus Bacteroides and related species, p. 3593-3608. In A. Balows, H. G. Truper, M. Dworkin, W. Harder, and K.-H. Schleifer (ed.), The prokaryotes, 2nd ed. Springer-Verlag, New York.

15. Shah, H. N., R. Bonnett, B. Mateen, and R. A. D. Williams. 1979. The porphyrin pigmentation of subspecies of Bacteroides melaninogenicus. Biochem. J. 180:45-50.

16. Shah, H. N., and M. D. Collins. 1980. Fatty acid and isoprenoid quinone composition in the classification of Bacteroides melaninogenicus and related taxa. J. Appl. Bacteriol. 48:75-87.

17. Shah, H. N., and M. D. Collins. 1983. Genus Bacteroides: a chemotaxonomical perspective. J. Appl. Bacteriol. 55:403-416.

18. Shah, H. N., and M. D. Collins. 1988. Proposal for reclassification of Bacteroides asaccharolyticus, Bacteroides gingivalis, and Bacteroides endodontalis in a new genus Porphyromonas. Int. J. Syst. Bacteriol. 38:128-131.

19. Shah, H. N., and M. D. Collins. 1990. Prevotella, a new genus to include Bacteroides melaninogenicus and related species formerly classified in the genus Bacteroides. Int. J. Syst. Bacteriol. 40:205-208.

20. Shah, H. N., and S. E. Gharbia. Heterogeneity among strains of Prevotella intermedia. Lett. Appl. Microbiol., in press.
21. Shah, H. N., S. E. Gharbia, and P. A. Lawson. 1991. Chemotaxonomic methods, p. 65-99. In P. N. Levett (ed.), Anaerobic microbiology: a practical approach. IRL Press, Oxford.

22. Shah, H. N., and R. A. D. Williams. 1982. Dehydrogenase patterns in the taxonomy of Bacteroides. J. Gen. Microbiol. 128:2955-2965.

23. Shah, H. N., R. A. D. Williams, G. H. Bowden, and J. M. Hardie. 1976. Comparison of the biochemical properties of Bacteroides melaninogenicus from human dental plaque and other sites. J. Appl. Bacteriol. 41:473-492.

24. Sutter, V. L., D. M. Citron, M. A. C. Edelstein, and S. M. Finegold. 1985. Wadsworth anaerobic bacteriology manual, 4th ed., p. 111-112. Star Publishing Co., Belmont, Calif.

25. Swindlehurst, C. A., H. N. Shah, C. W. Parr, and R. A. D. Williams. 1977. Sodium dodecylsulphate-polyacrylamide gel electrophoresis of polypeptides from Bacteroides melaninogenicus. J. Appl. Bacteriol. 43:319-324.

26. van Steenbergen, T. J. M., J. J. de Soet, and J. de Graaff. 1979. DNA base composition of various strains of Bacteroides melaninogenicus. FEMS Microbiol. Lett. 5:127-130.

27. van Steenbergen, T. J. M., C. A. Vlaanderen, and J. de Graaff. 1982. Deoxyribonucleic acid homologies among strains of Bacteroides melaninogenicus and related species. J. Appl. Bacteriol. 53:269-276.

28. van Steenbergen, T. J. M., A. J. van Winkelhoff, D. Mayrand, D. Grenier, and J. de Graaff. 1984. Bacteroides endodontalis sp. nov., an asaccharolytic black-pigmented Bacteroides species from infected dental root canals. Int. J. Syst. Bacteriol. 34:118 120. 